\title{
Ontwikkelingen in supply chain management
}

\section{Marc Wouters}

SAMENVATTING Het doel van dit artikel is om ontwikkelingen in supply chain management (SCM) te bespreken. SCM gaat over de inrichting en besturing van ketens van voortbrengingsprocessen. Aan bod komen: economische afwegingen rond leverbetrouwbaarheid, stroomlijnen van Europese interne supply chains, betere coördinatie van operationele activiteiten tussen bedrijven, en productontwerp voor de supply chain. De belangrijkste implicaties voor het werk van de controller en de accountant worden besproken, onder meer dat risicobeheersing belangrijker wordt wanneer supply chains verfijnder en efficiënter worden ingericht en bestuurd.

RELEVANTIE VOOR DE PRAKTIJK Dit artikel schetst een beeld van actuele ontwikkelingen in supply chain management (SCM) in het bedrifsleven. Het legt een verbinding tussen operationele aspecten en het werk van de controller en de accountant. Zij krijgen daardoor beter inzicht in wat er speelt en hoe zij een rol kunnen spelen in de economische analyse van supply chain-beslissingen, hoe zij systemen voor prestatiemeting en kostprijsberekening kunnen aanpassen en hoe risicobeheersing belangrijker wordt omdat supply chains efficiënter maar ook kwetsbaarder worden.

\section{Inleiding: supply chains}

Het doel van dit artikel is om ontwikkelingen in supply chain management te bespreken. Supply chain management (SCM) gaat over de inrichting en besturing van ketens van voortbrengingsprocessen. Het lijkt zich dus in de eerste plaats af te spelen buiten het werkveld van de controller of de accountant, maar toch kunnen ontwikkelingen in SCM wel degelijk gevolgen hebben voor het werk van de controller of de accountant. Dit artikel is gebaseerd op literatuur in SCM en op diverse onderzoeksprojecten van de auteur.

Het begrip 'supply chain' definiëren we hier als een keten van voortbrengingsprocessen die zich kan uitstrekken over verschillende bedrijven. Er is dus niet noodzakelijkerwijs één eigenaar van de supply chain die alle beslissingsbe- voegdheden heeft. De keten is gericht op het tot stand brengen van een product voor eindgebruikers. Bijvoorbeeld in de supply chain van notebook computers zijn eindgebruikers de consumenten of bedrijven die notebooks kopen. Andere partijen in de supply chain zijn winkels (zoals de Media Markt), distributiebedrijven (zoals Maersk en J.B. Hunt), computerfabrikanten (zoals Dell en HP), onderdelenfabrikanten (zoals Intel), maar ook de bedrijven die voor deze fabrikanten de productieapparatuur maken (zoals ASML en Applied Materials). We gebruiken de term 'product' voor tastbare producten voor consumenten of business-to-business klanten, maar ook voor productiesystemen en diensten.

We onderscheiden verschillende soorten beslissingen, zie ook tabel 1:

(1) Beslissingen over de inrichting van de supply chain; deze betreffen bijvoorbeeld het aantal en de locaties van fabrieken, de technologie per fabriek (waardoor wordt bepaald welke producten waar gemaakt kunnen worden) en de productiecapaciteit per fabriek. Inrichtingsbeslissingen betreffen ook het aantal en de locaties van distributiecentra en de keuze van transportmodaliteiten.

(2) Beslissingen over de besturing van de supply chain, bijvoorbeeld de planning van wat er daadwerkelijk geproduceerd en getransporteerd wordt (gegeven de infrastructuur).

(3) Beslissingen over het ontwerp van de producten; hierbij gaat het om productkenmerken die invloed hebben op de inrichting en besturing van de supply chain.

Supply chain-beslissingen zijn lastig omdat verschillende doelen een rol spelen, zoals het doel om de kosten laag te houden, maar ook het doel om (bijna) altijd aan de klantenvraag te voldoen (Melnyk e.a., 2010). Deze doelen zijn strijdig. Daarnaast is innovatie van belang: nieuwe producten en diensten aanbieden. En bovendien zijn veiligheid (zoals bij voeding en medicijnen), duurzaamheid (zoals met betrekking tot energieverbruik) en herstel- 
Tabel 1 Structuur van het artikel

\begin{tabular}{|c|c|c|}
\hline Beslissingen & Onderwerpen (paragraaf) & Implicaties voor controller en accountant \\
\hline (1) Inrichting van de supply chain & $\begin{array}{l}\text { Market mediation (§ 2) } \\
\text { Europese supply chains (§ 3) }\end{array}$ & $\begin{array}{l}\text { - Onderbouwen market mediation beslissingen (afweging tussen voorraad, } \\
\text { flexibiliteit, en nee-verkopen) } \\
\text { - Prestatiemeting en kostprijsberekening in Europa } \\
\text { - (Des)investeringsbeslissingen } \\
\text { - Shared service centers } \\
\text { - Juridische structuur }\end{array}$ \\
\hline (2) Besturing van de supply chain & $\begin{array}{l}\text { Betere coördinatie van } \\
\text { operationele activiteiten (§ 4) }\end{array}$ & $\begin{array}{l}\text { - Koppelen van informatiesystemen } \\
\text { - Aanpassen administratieve afhandeling van transacties } \\
\text { - Aanpassen prestatiemeting op interfaces } \\
\text { - Identificeren van besparingsmogelijkheden en meten van resultaten }\end{array}$ \\
\hline (3) Productontwerp & $\begin{array}{l}\text { Productontwikkeling voor de } \\
\text { supply chain (§ 5) }\end{array}$ & $\begin{array}{l}\text { - Onderbouwen van productontwerpbeslissingen (bijvoorbeeld de afweging } \\
\text { van de kosten en opbrengsten van een modulair ontwerp) }\end{array}$ \\
\hline \\
\hline $\begin{array}{l}\text { Dit brengt met zich mee dat supply } \\
\text { controller en de accountant ( }(6)\end{array}$ & fijnder en efficiënter worden in & ht en bestuurd, en daardoor wordt risicobeheersing belangrijker voor de \\
\hline
\end{tabular}

lingsvermogen (zoals bij natuurrampen, stakingen of falende IT-systemen) van belang.

De opbouw van dit artikel is als volgt, zie ook tabel 1. Paragraaf 2 gaat over de belangrijkste economische afwegingen rond afstemming van productie en vraag. Paragraaf 3 gaat over stroomlijnen van Europese supply chains. In paragraaf 4 komt aan bod hoe operationele activiteiten beter kunnen worden gecoördineerd. Paragraaf 5 gaat over productontwikkeling voor de supply chain. De implicaties voor de controller en accountant komen aan bod in paragraaf 6, vooral met betrekking tot risicobeheersing in supply chains. De samenhang van de onderwerpen is weergegeven in tabel 1. Behalve het eigen onderzoek heeft ook de actualiteit meegespeeld bij de selectie van onderwerpen. Specifiek hebben we gekeken naar onderwerpen die aan de orde komen in het recente nummer van MIT Sloan Management Review (Winter 2010) dat extra aandacht besteedt aan supply chain management.

\section{Market mediation}

Supply chains zijn nogal verschillend ingericht (Kopczak en Johnson, 2003). Neem bijvoorbeeld een blik soep dat voor 89 eurocent bij de supermarkt in het schap staat. Deze supply chain is volledig ingericht op lage kosten van productie en distributie, nauwelijks reclame (huismerk), nauwelijks verandering van product en verpakking, en een klein assortiment (weinig variëteit). In de supply chain voor mode en voor consumentenelektronica zijn de kosten ook belangrijk, maar de marges zijn aanmerkelijk hoger. Er is ruimte om veel variëteit aan te bieden en door middel van afprijzen de oude modellen kwijt te raken, en dat is ook nodig omdat het assortiment zeer vaak verandert. Productontwikkeling is belangrijk. De supply chain van een webbedrijf is weer een ander verhaal, vooral als er zoals bij Dell ook klantgestuurde productie plaatsvindt. Nu gaat er veel geld naar de website, er is geïnvesteerd in flexibiliteit van de fabriek, en distributie 'per stuk' rechtstreeks naar de consument is relatief duur, maar wel snel en er is weinig voorraad in de keten.

Een centraal begrip om de inrichting van supply chains te begrijpen, is 'market mediation' (Fisher, 1997), dat kan worden gedefinieerd als afstemming van hoeveelheid en variëteit van producten die door de supply chain worden geproduceerd en die door eindgebruikers worden gevraagd. Er kunnen verschillende maatregelen genomen worden om deze afstemming te bewerkstelligen. Met betrekking tot het bestaande productassortiment gaat het in essentie om drie maatregelen: voorraden, flexibiliteit, en neeverkopen. Idealiter zou je als supply chain precies maken wat door eindgebruikers wordt gevraagd, maar dat lukt meestal niet. De levertijden zijn bijvoorbeeld (veel) korter dan op die manier door de supply chain zou kunnen worden gerealiseerd, of de vraag fluctueert zodanig dat het niet bij te houden is. Voorraden zorgen ervoor dat productieactiviteiten in de supply chain tot op zeker hoogte kunnen worden ontkoppeld van de vraag. Er is dus een afweging tussen de kosten van voorraad en de kosten van flexibiliteit. En bovendien wordt bewust geen onbeperkte leverbetrouwbaarheid aangeboden, maar accepteert een bedrijf een bepaalde mate van nee-verkopen omdat de kosten van nog meer voorraad en nog meer flexibiliteit niet meer opwegen tegen de extra geboden leverbetrouwbaarheid. 
De kosten van voorraad zijn, door een operationele bril gezien, nog wat genuanceerder dan alleen de kosten van werkkapitaal op de balans. Vanzelfsprekend zijn er de financieringskosten, maar er is meer:

- Producten op voorraad sluiten soms onvoldoende aan op de gevraagde producten en dan zijn er kosten als gevolg van ombouwen, aanpassen, of afprijzen.

- Componenten zijn soms onderhevig aan prijserosie (zoals in de elektronica) en moeten elk kwartaal worden afgewaardeerd. Anders gezegd: als een bedrijf de voorraad niet heeft en de onderdelen later koopt, dan is de inkoopprijs inmiddels lager.

- Componenten en producten kunnen onderhevig zijn aan 'veroudering' en daarom moeten voorraden soms worden afgewaardeerd of weggegooid. Denk an voedingsmiddelen of medicijnen die een beperkte houdbaarheid hebben, kleding die niet meer in de mode is of elektronische componenten die technisch achterhaald zijn.

- Soms zijn producten duur om op te slaan, bijvoorbeeld doordat deze veel ruimte vragen, speciale klimatologische condities vereisen of moeten worden bewaakt.

Het zal duidelijk zijn dat sommige producten veel duurder zijn om op voorraad te houden dan andere, ook bij gelijkblijvende financieringskosten, en dat heeft invloed op de gekozen market mediation-maatregelen.

De kosten van flexibiliteit zijn ook veelzijdig, maar deze zijn vaak minder duidelijk zichtbaar. Er zijn daarom situaties waarin het management nogal eenzijdig de nadruk legt op voorraadreductie, zonder de consequenties voor verlaging van de leverbetrouwbaarheid of verhoging van de kosten voor noodzakelijke flexibiliteit in ogenschouw te nemen (Corbey en Jansen, 1993). Voorbeelden van kosten van flexibiliteit zijn:

- Reservecapaciteit, zodat snel extra hoeveelheid vraag kan worden geproduceerd. Anders gezegd, als de vraag per week 500 bedraagt, dan zou een productiecapaciteit van 100 per dag (bij 5 werkdagen per week) gemiddeld genoeg moeten zijn. Maar extra vraag op bijvoorbeeld maandag betekent ofwel dat deze pas later in de week aan de beurt komt (en dus is de levertijd langer) of dat voorraad aangehouden moet worden. Als de vraag in $95 \%$ van de gevallen schommelt tussen 50 en 150 per dag, dan is een productiecapaciteit van 150 per dag nodig om een redelijke servicegraad te kunnen bieden zonder voorraad aan te houden. De reservecapaciteit is dus $750-500=250$ stuks per week. Dit brengt extra kosten met zich mee.

- Flexibele productiesystemen, zodat de gevraagde mix van producten ook precies zo kan worden geproduceerd. Denk bijvoorbeeld aan omschakelen tussen verschillende kleuren lak in een autofabriek of aan een assem- blagelijn waarop drie-, vier- en vijfdeursmodellen door elkaar kunnen worden geproduceerd. Omstellen tussen verschillende soorten producten moet snel kunnen en dit vergt mogelijk grotere investeringen dan systemen die geen voorzieningen kennen voor snel omstellen.

- Snelle distributiesystemen, bijvoorbeeld door per vliegtuig van de fabriek in Azië naar de afzetmarkt in Europa te vervoeren in plaats van per container. Dit is duidelijk duurder, maar het betekent ook dat in Europa minder voorraad nodig is.

Het voorgaande suggereert een eenvoudig onderscheid tussen productie 'op order' versus 'op voorraad', maar dit ligt genuanceerder. Van belang is het klantorderontkoppelpunt (Corbey en Jansen, 1993). Dit is zodanig gedefinieerd dat stroomopwaarts van dit punt de productieplanning gebaseerd is op een vraagvoorspelling en stroomafwaarts is de planning gebaseerd op echte klantorders. Bijvoorbeeld: als Dell de computers in de fabriek in Ierland produceert 'op order', dan betekent dit concreet dat de assemblage klantordergestuurd is. Maar veel onderdelen hebben een levertijd van enige weken, dus die worden al eerder op grond van een vraagvoorspelling besteld. De onderdelenvoorraad is dus het klantorderontkoppelpunt.

Een ander voorbeeld: stel dat een bedrijf uit voorraad levert en vroeger in elk land in Europa magazijnen met voorraden had, maar deze voorraden nu heeft geconsolideerd in een centraal magazijn voor heel Europa. Vanuit dat punt gaan orders rechtstreeks naar klanten. Het klantorderontkoppelpunt is stroomopwaarts verschoven van de landen naar het centrale distributiecentrum. In feite is het onderscheid 'op voorraad' of 'op order' dus genuanceerder. Door het klantorderontkoppelpunt verder stroomopwaarts te leggen, zijn besparingen mogelijk die te maken hebben met voorraadkosten, maar worden hogere eisen gesteld aan de flexibiliteit en snelheid van die processen die daarna (dus nadat de klant heeft besteld) nog moeten worden uitgevoerd.

Tot nu toe ging het over operationele afstemming van vraag en aanbod van bestaande producten. Daarnaast is het van belang om beslissingen met betrekking tot productontwikkeling te bekijken vanuit market mediation-perspectief. Ook dan zijn diverse afwegingen van belang, zoals tussen:

- de snelheid van de introductie van nieuwe producten (time-to-market);

- de kosten van productontwikkeling;

- de kostprijs van het product zelf.

Een goed voorbeeld is de halfgeleiderindustrie. De introductie van nieuwe technologie in deze supply chain wordt nauwkeurig tussen verschillende bedrijven afgestemd via de zogenaamde 'technology roadmaps' (Miller en O'Leary, 
2007). Dat betekent dat het voor een bedrijf cruciaal is om bepaalde nieuwe systemen op tijd af te hebben, bijvoorbeeld voor een bepaalde technologiebeurs. Men zal in een aantal gevallen extra geld besteden om productontwikkelingsprojecten te versnellen of de productontwikkeling afronden en een hogere kostprijs accepteren (omdat er geen tijd meer is om het ontwerp aan te passen om de kostprijs te reduceren) (Davila en Wouters, 2004). Er zijn dus afwegingen tussen time-to-market, de kosten van productontwikkeling en de kostprijs.

De gevolgen voor de controller en accountant zijn dat men in staat moet zijn om afwegingen tussen de kosten van market mediation te helpen analyseren. Zoals besproken, bestaan er immers wezenlijke economische afwegingen tussen verschillende maatregelen die kunnen worden genomen. Het is voor de controller en accountant een uitdaging om voldoende kennis te hebben van het operationele proces en van keuzes die tijdens productontwikkeling kunnen worden gemaakt, zodat ze worden gezien als zinvolle partners die ook vooraf bij beslissingen betrokken kunnen worden.

\section{Interne Europese supply chains}

Bedrijven in Europa hebben hun interne supply chains kritisch onder de loep genomen (Van Hoek, Vos en Commandeur, 1999). Dit moet vooral worden gezien tegen de achtergrond van verdergaande Europese integratie van ondernemingen (Groot en Wouters, 1999). Distributie in Europa is tegenwoordig sneller, er is sprake van inkopen op Europees niveau waarbij afnemers intern de prijzen van dezelfde leverancier in verschillende landen vergelijken. Bovendien worden Amerikaanse en Japanse bedrijven in Europa niet gehinderd door historische banden en de barrières van de landencultuur in Europa, en dit laat zien dat ook eenvoudiger concepten mogelijk waren dan tot die tijd door Europese bedrijven gehanteerd werden. Deze ontwikkelingen vertalen zich in kostendruk en hogere eisen aan de supply chain (Knaapen e.a., 2003). We zien een aantal gemeenschappelijke elementen van Europese supply chains.

Bedrijven streven naar productharmonisatie. Dat bekent dat er minder merken in Europa in de lucht gehouden worden, dat per merk de variëteit en complexiteit van het assortiment worden gereduceerd door minder verschillende recepten, onderdelen, specificaties, verpakkingen en dergelijke. Productontwikkeling wordt centraal aangestuurd, ook als deze niet op een locatie is geconcentreerd. Deze harmonisatie kan leiden tot kostenvoordelen in productontwikkeling (er hoeven minder varianten ontwikkeld te worden) en tot schaalvoordelen in de productie (van de resterende producten worden immers meer eenheden gemaakt). Bovendien kunnen innovaties en commerciële inspanningen meer worden geconcentreerd.

Een voorbeeld is het merk Magnum van Unilever, dat in diverse markten is geïntroduceerd, terwijl lokaal ook verschillende merken ijs worden gehanteerd. Het merk Magnum is daar als het ware naast gezet. Voor dit merk kan meer worden geïnvesteerd in productontwikkeling en er kunnen veel duurdere commercials worden gemaakt, omdat die in verschillende markten worden gebruikt. En er zijn schaalvoordelen in de productie, in vergelijking met een situatie dat een groter aantal verschillende producten zou worden geproduceerd. Daarnaast zien we dat dit bedrijf merken afstoot en binnen een merk de variëteit in Europa reduceert. Soms gebeurt dit subtiel: de merknamen voor ijs in Europa zijn veelal gehandhaafd (zoals Iglo, Algida, Frigo, Streets, Frisko, Langnese, Eskimo en Wall's), terwijl voor al deze merken het logo wel is gestandaardiseerd. Dit is het hartvormige logo dat wij in Nederland meteen met Ola associëren. Unilever noemt dit het 'Heartbrand'. Deze combinatie van standaard logo en verschillende merken maakt het mogelijk om in sommige situaties een verpakking te hanteren die alleen dit logo bevat, maar niet een landspecifieke merknaam (die denkt de consument er vanzelf bij). waardoor een product alsnog in verschillende landen kan worden gedistribueerd.

Bedrijven streven ook naar een Europese supply base. Dat betekent minder fabrieken, die bovendien meer gespecialiseerd zijn in een beperkt aantal technologieën. Als we een matrix opstellen met daarin de fabrieken (rijen) en de technologieën (in kolommen), dan wordt het aantal rijen kleiner en bovendien wordt het aantal lege cellen in de matrix groter. Dit biedt schaalvoordelen in productie, omdat een product immers in een groter volume per fabriek wordt geproduceerd, maar ook kan technische expertise voor procesinnovatie meer worden geconcentreerd. Daardoor kunnen meer innovaties worden ontwikkeld (meer specialisten in een bepaalde technologie die op een locatie werken) en deze innovaties kunnen sneller (want in minder locaties) doorgevoerd worden. Een Europese supply chain betekent veelal ook minder distributiecentra, die elk een grotere regio bedienen. In deze distributiecentra worden voorraden geconsolideerd en dat heeft ook zin, want de geharmoniseerde producten kunnen ook in een grotere regio verkocht worden.

De beschreven standaardisatie en vereenvoudiging zijn ook begrijpelijk in het kader van de verschillende soorten kostenveroorzakers die in activity-based costing worden genoemd, zoals product sustaining costs en facility sustaining costs. Kosten worden niet alleen veroorzaakt door volume, maar ook door 
complexiteit. Het aantal verschillende producten, fabrieken, leveranciers, klanten enzovoort bepaalt ook de totale kosten, evenals het aantal keren dat inkooporders, productieorders en dergelijke worden opgestart. Minder variëteit kan daardoor bijdragen aan kostenreductie.

Soms strekt de inrichting van een Europese supply chain zich ook uit tot de ondersteunende processen. In zogenaamde 'shared service centers' worden voor diverse landen bijvoorbeeld inkomende facturen verwerkt en betaald, facturen voor klanten opgesteld en verstuurd, de personeelsadministratie verzorgd en ERP-systemen in de lucht gehouden.

De wijzigingen van het assortiment en de supply base gaan vaak samen met de inrichting van een pan-Europese organisatie, die in de plaats komt van een organisatiestructuur met daarin landen als profit centers die hun eigen fabrieken, assortiment, R\&D en marketing omvatten. De fabrieken en distributiecentra worden veelal ondergebracht in een organisatorische eenheid voor geheel Europa (of EMEA) die de inrichting van de supply base aanpast en de operationele besturing optimaliseert. Productontwikkeling wordt dan in de eerste plaats gedaan voor marktsegmenten die vaak binnen Europa en niet zozeer per land worden onderscheiden. Het management van de Europese organisatie vereist dat prestatiemeting wordt aangepast om een beter overzicht van de supply chain te krijgen (vanaf leveranciers tot aan levering aan klanten) (Lohman e.a., 2004). Standaardisatie van prestatiemeting maakt het mogelijk om zaken in verschillende Europese fabrieken te vergelijken, maar ook in verschillende distributiecentra, in verschillende markten en voor verschillende leveranciers en klanten. Het is van belang om medewerkers nadrukkelijk te betrekken bij de ontwikkeling van prestatiemeting in supply chains (Wouters en Sportel, 2005; Wouters, Stertefeld en Wilderom, 2007; en Wouters en Wilderom, 2008).

In de context van een meer gecentraliseerde Europese organisatie kan het bovendien voordelen bieden om de juridische structuur aan te passen. Er kan bijvoorbeeld gekozen worden voor een structuur waarbij fabrieken door de moedermaatschappij betaald worden voor de bewerkingen die ze uitvoeren aan het materiaal dat de moedermaatschappij bezit, aflevert bij de fabriek en na bewerking weer ophaalt. Op dezelfde manier worden de verkoopkantoren dan soms alleen nog betaald voor het verkopen van goederen die eigendom blijven van de moedermaatschappij. Er zijn verschillende juridische vormen om dit te regelen, maar de kern is dat de fabrieken en verkoopkantoren in feite geen eigenaar worden van de producten. We willen hier niet bespreken of dit al of niet belastingvoordelen biedt (door de verschuiving van risico's en winstge- vendheid), maar ons argument is vooral dat hierdoor de administratieve systemen binnen de onderneming vereenvoudigd worden. Intercompany pricing en facturering wordt vermeden of vereenvoudigd, want er worden alleen vergoedingen voor bepaalde activiteiten betaald.

Het zal duidelijk zijn dat de geschetste ontwikkelingen veel gevolgen kunnen hebben voor de controller en accountant. Aan de orde zijn immers veranderingen en standaardisatie van prestatiemeting en kostprijsberekening, aanpassingen van de supply base (concreet: sluiten van sites, investeren en desinvesteren op de resterende sites), shared services en nieuwe juridische structuren.

\section{Betere coördinatie van operationele activiteiten}

Met coördinatie van operationele activiteiten bedoelen we coördinatie van activiteiten van verschillende partijen in de supply chain. Verschillende ontwikkelingen kunnen worden genoemd; zie ook het artikel van Kopczak en Johnson (2003) voor een overzicht. Met 'betere' coördinatie wordt hier een zodanige coördinatie bedoeld dat de kosten in de totale keten lager worden en/of beter voldaan wordt aan de vraag van de eindgebruikers. Met andere woorden: een verbeterde market mediation en/of lagere kosten daarvoor.

Een belangrijk aspect van betere coördinatie van operationele activiteiten is om opslingereffecten te verminderen. De vraag van de eindgebruiker varieert meestal over verschillende periodes, maar er is sprake van een opslingereffect als stroomopwaarts de vraag meer varieert dan die van de eindgebruiker (Fransoo en Wouters, 2000). Er in deze definitie sprake van een opslingereffect als de variatiecoëfficiënt van de vraag stroomopwaarts van een schakel in de keten groter is dan de variatiecoëfficiënt van de vraag stroomafwaarts van diezelfde schakel (Fransoo en Wouters, 2000). De variatie wordt dan versterkt stroomopwaarts doorgegeven. Dit lijkt in eerste instantie onnodig, maar toch komt het voor. Daarvoor zijn verschillende oorzaken, zoals dat er stroomopwaarts in grotere minimale hoeveelheden besteld moet worden (bijvoorbeeld minimaal een gehele pallet). Maar wezenlijk is dat onzekerheden en vertragingen 'opgestapeld' worden. Stel dat in de zomer op een woensdag de weersverwachting voor het weekeinde een hoge temperatuur aangeeft. De supermarkten zullen dan waarschijnlijk extra producten als barbecuevlees en bier bestellen. De distributiecentra (DC's) van de supermarktketens worden geconfronteerd met deze bestellingen en de planners in de DC's weten ook dat er goed weer verwacht wordt. Zij zijn geneigd de bestellingen ook te verhogen, omdat ze veelal niet weten hoeveel extra de supermarkten al besteld hebben en hoeveel er nog in de winkels op voorraad is. Voor de producenten is de situatie 
nog onoverzichtelijker. Nog weer iets later krijgen zij de bestellingen van de DC's door. Bij het plannen van de productie zullen ze eventueel rekening houden met de weersverwachting, maar ze weten niet hoeveel voorraad stroomafwaarts in de keten beschikbaar is en bovendien hebben ze te maken met hun eigen afwegingen rond seriegrootte en voorraden. Stel nu dat op vrijdag het weer omslaat. Iedereen begint nu bestellingen te verlagen, vaak weer met wat vertraging. De producenten zijn mogelijk nog aan het overwerken terwijl in de winkels de vraag al is ingestort.

Deze opslingereffecten kunnen onder meer worden verminderd door meer informatie uit te wisselen (Kopczak en Johnson, 2003). Als de producent rechtstreeks zicht heeft op de actuele vraag in de winkel (wat er gescand wordt bij de kassa, de zogenaamde 'point of sale'-gegevens) en op de voorraden in de keten, dan kan er sneller en nauwkeuriger gepland worden. Bovendien kan de producent betere modellen ontwikkelen waarmee de vraag van de consument kan worden voorspeld, bijvoorbeeld afhankelijk van het weer, het seizoen, feestdagen en prijsaanbiedingen.

In toenemende mate verwachten afnemers dergelijke expertise op het gebied van consumentengedrag (welke factoren op welke manier de vraag naar producten beïnvloeden). Neem het voorbeeld dat een supermarktorganisatie en een producent van bier afspreken om in een bepaalde week in de winkel korting te geven op het bier. Het is dan belangrijk om te voorspellen hoeveel extra bier van het desbetreffende merk zal worden verkocht in die week en hoeveel minder van andere merken bier. Ook zal er waarschijnlijk minder worden verkocht van het desbetreffende merk in de weken na de prijsverlaging. Op grond hiervan kan worden gepland hoeveel voorraad er beschikbaar moet zijn in de DC's van de supermarktorganisatie in de weken voor, tijdens en na de prijsaanbieding.

Bovendien wordt soms de verantwoordelijkheid voor distributie en voorraad bij de producent gelegd ('vendormanaged inventory'). Dat betekent dat de supermarktorganisatie niet meer bestelt bij de producent, maar dat er afspraken gemaakt worden over de beschikbaarheid van voorraad in het DC van de supermarktorganisatie. Binnen randvoorwaarden (zoals de beschikbare ruimte in het DC en aflevertijden bij het DC) moet de leverancier bepalen wat er aan het DC wordt geleverd teneinde een bepaalde beschikbaarheid te realiseren.

Tot nu toe zijn we ingegaan op wat erbij komt kijken om aan de soms hectische vraag van klanten te voldoen (de klantenvraag is een logistiek probleem dat moet worden opgelost). Maar soms werkt het omgekeerd: de vraag van klanten kan beïnvloed worden als middel om problemen in de supply chain op te lossen (revenue management). Hotels en vliegtuigmaatschappijen zijn bekende voorbeelden waarbij de prijs voortdurend aangepast wordt om de vraag te beïnvloeden. Dergelijke bedrijven kennen immers vooral vaste kosten en de productie kan niet op voorraad worden gelegd: het vliegtuig vertrekt en lege stoelen kunnen niet worden 'bewaard' en later verkocht. Men onderscheidt daarom verschillende marktsegmenten en biedt capaciteit aan tegen verschillende condities en prijzen. Bovendien wordt de prijs aangepast als de capaciteit extra snel of langzaam wordt verkocht. Maar ook in supply chains met goederen wordt dit toegepast. Dell produceert weliswaar veel computers pas nadat de klant deze heeft gespecificeerd en besteld, maar de computeronderdelen (zoals processors, disk drives en geheugen) moeten ruim vooraf worden besteld. Als sommige onderdelen minder worden verkocht dan gepland, dan wordt de prijs aangepast teneinde de vraag te beïnvloeden. Dell noemt dit 'sell what you have'. Zie ook Stewart en O'Brian (2005) over Dell. Vooral in supply chains die direct aan eindgebruikers verkopen, kan snel worden gereageerd door middel van prijsaanpassingen.

Nog een ontwikkeling die te maken heeft met betere coördinatie van operationele activiteiten, is remote frequency identification (RFID) (Tajima, 2007). Dit betreft chips die in een product of verpakking worden ingebouwd en die via antennes kunnen worden gelezen en waar soms ook gegevens op kunnen worden weggeschreven. Deze chips worden steeds goedkoper en kunnen op termijn op individuele consumentverpakkingen worden aangebracht. Waarom heeft dit waarschijnlijk vergaande consequenties voor de operationele besturing van de supply chain? Dit is omdat het mogelijk wordt voorraden en goederenstromen in veel meer detail te volgen en bij te sturen. Neem bijvoorbeeld verse maaltijden in de supermarkt met een houdbaarheid van acht dagen na productie. Deze zijn moeilijk logistiek te sturen met betrekking tot beschikbaarheid, houdbaarheid en voorraadkosten. Idealiter grijpt de consument zelden mis in het schap, heeft een verpakking een bepaalde minimale en gemiddelde houdbaarheid als de consument deze koopt (bijvoorbeeld minimaal twee dagen en gemiddeld vier) en hoeft er niet meer dan een bepaald percentage te worden afgeprijsd of weggegooid. De parameters voor beschikbaarheid, houdbaarheid en afprijzen/ weggooien kunnen vooraf worden berekend: dit heeft alles te maken met 'market mediation' zoals eerder besproken. Maar meten van de realisatie is vrijwel onmogelijk op basis van de huidige technologie met de streepjescode. Deze is statisch en bevat geen gegevens over de houdbaarheidsdatum van een specifieke verpakking. Het is dus niet mogelijk om in de kassa bij het scannen te registreren 
hoeveel dagen houdbaarheid de consument koopt. Als er wordt afgeprijsd of weggegooid, is het in principe mogelijk om de kosten per streepjescode te registreren, maar veelal gebeurt dit niet. En hoe vaak de consument misgrijpt, is niet automatisch te meten. Maar met een RFID-chip per verpakking en aanvullende apparatuur wordt het mogelijk om precies in de winkel, en ook verder stroomopwaarts, de goederenstromen en voorraden te volgen.

Een laatste ontwikkeling om hier te noemen, betreft beperking van $\mathrm{CO}_{2}$-uitstoot in distributie (Golicic, Boerstler en Ellram, 2010), omdat dat één van de activiteiten is die veel bijdraagt aan energieverbruik en $\mathrm{CO}_{2}$-uitstoot. Transport is vaak relatief goedkoop en in veel supply chains hoeft er daarom niet veel rekening mee gehouden te worden bij beslissingen over de inrichting van de supply chain. Maar transport kan duurder worden, bijvoorbeeld doordat betaald moet worden voor $\mathrm{CO}_{2}$-uitstoot, en energiebesparing kan belangrijker worden voor het imago van het bedrijf. Er kan gekeken worden naar mogelijkheden om modernere en efficiëntere technologie te gebruiken, afstanden in distributie te verkorten en andere transportmiddelen te gebruiken. Railvervoer en scheepvaart zijn gunstiger dan wegtransport. Ook slimmere transportplanning kan een bijdrage leveren: kortere routes en betere benutting van de beschikbare capaciteit (zoals vollere vrachtwagens). Veel bedrijven hebben nog geen integraal overzicht van energieverbruik en $\mathrm{CO}_{2}$-uitstoot en men werkt aan programma's met doelstellingen en meetsystemen.

Deze verschillende initiatieven om operationele activiteiten in de supply chain beter te coördineren, kunnen leiden tot significante kostenbesparingen. De meting hiervan is een aandachtspunt voor de financiële functie, maar ook de verdeling: er zijn immers vaak meerdere partijen bij betrokken. De verdeling is vooral lastig wanneer de ene partij investeringen moet doen en/of hogere operationele kosten gaat maken, terwijl de besparingen bij de andere partij vallen (Wouters, 2007). Het is dan belangrijk om allereerst gezamenlijk de totale kostenbesparing te ontwikkelen en dit te ontkoppelen van de onderhandeling over de verdeling. Daarmee wordt niet naïef bedoeld dat de deelnemers er maar op moeten vertrouwen dat na het behalen van een kostenbesparing de verdeling wel goed zal uitpakken. Tijdens de ontwikkeling van de supply chain-verbeteringen zal echter al de garantie moeten bestaan dat eerst ook nog overeenstemming bereikt moet worden over de verdeling voordat daadwerkelijk tot invoering van het supply chaininitiatief wordt overgegaan.

De meting van kostenbesparingen als gevolg van SCMinitiatieven is niet gemakkelijk (Johnson en Leenders, 2010), onder meer omdat er natuurlijk verschillende zaken tegelijkertijd in een bedrijf veranderen. Als de kosten lager worden, in welke mate is dat dan veroorzaakt door een bepaalde SCM-verbetering? Verfijndere kostensystemen zoals total cost of ownership (Wouters, 2006; Morssinkhof, Wouters en Warlop 2005; Wouters, Wynstra en Anderson, 2005) kunnen voor een deel helpen om een beter inzicht te krijgen in kostenbesparingen. Ook is het van belang om de geplande verbeteringen en besparing zo concreet mogelijk vooraf te specificeren en meetbaar te maken. Als een project bijvoorbeeld uitgevoerd wordt om de voorraadhoogte van een bepaalde groep producten in een bepaald distributiecentrum met $18 \%$ te verlagen, dan wordt dat vastgelegd en bijgehouden. Dat zegt meer dan een overall financieel cijfer over voorraden (dat inderdaad door nog veel meer factoren wordt beïnvloed). Verder is het van belang om de voorspelde besparingen ook te verwerken in de budgetten (Johnson en Leenders, 2010).

Er kunnen veel gevolgen zijn voor de controller en accountant. Een natuurlijke rol is om besparingsmogelijkheden financieel te analyseren en de resultaten te meten. Nieuwe werkwijzen kunnen ook leiden tot een andere prestatiemeting, vooral op de interface met een ander bedrijf. Bijvoorbeeld bij vendor-managed inventory moet beschikbaarheid gemeten worden in plaats van leverbetrouwbaarheid. De administratieve afhandeling verandert soms ook, bijvoorbeeld betalen op basis van verbruik in plaats van levering. Daarnaast kunnen de controller en accountant betrokken zijn bij SCM-initiatieven die met zich meebrengen dat informatiesystemen worden gekoppeld met andere bedrijven.

\section{Productontwikkeling voor de supply chain}

Productontwikkeling wordt hier besproken omdat dit gevolgen heeft voor de inrichting van supply chains (Randall en Ulrich, 2001). We bespreken een aantal thema's: gemeenschappelijkheid van onderdelen, beperken en uitstellen van productdifferentiatie, en modulair productontwerp. Ramdas (2003) en Labro (2004) geven een goed overzicht van deze literatuur. Cooper en Slagmulder (2004) geven nog een breder overzicht van technieken voor reduceren van kosten.

Gebruikmaken van gemeenschappelijke onderdelen bij productontwikkeling is een belangrijke beslissing. Een gegeven assortiment eindproducten kan veelal tot stand worden gebracht met een meer of minder groot aantal verschillende onderdelen (componenten en subassemblages). Meer gemeenschappelijkheid brengt kosten en besparingen met zich mee (Labro, 2004). Besparingen hebben bijvoorbeeld betrekking op de volgende aspecten:

- Doordat er minder componenten ontwikkeld hoeven te worden, zijn besparingen in R\&D mogelijk. Het kan 
echter zijn dat hierdoor de resterende componenten ingewikkelder worden (omdat deze voor meer eindproducten geschikt moeten zijn) en daardoor de ontwikkelkosten per component hoger worden (maar het is nog steeds de bedoeling dat de totale ontwikkelkosten lager zijn).

- Doordat per component meer stuks worden geproduceerd of ingekocht, kunnen schaalvoordelen leiden tot lagere kosten.

- Een kleiner assortiment zal veelal ook leiden tot lagere voorraadkosten.

Dergelijke besparingen kunnen worden vergeleken met extra kosten als gevolg van gemeenschappelijkheid van onderdelen, zoals:

- Met de gemeenschappelijke onderdelen moeten voor alle eindproducten waarin deze ingebouwd worden de specificaties gerealiseerd kunnen worden. Dat betekent dat een bepaald onderdeel de beste specificaties moet kunnen realiseren van de set eindproducten waarin het wordt ingebouwd, en voor andere eindproducten in deze set zal hetzelfde onderdeel soms 'te goed' en normaal gesproken dus te duur zijn. Dit wordt ook wel 'overspecificatie' of 'excess capability' (Ulrich, 1995) genoemd.

- Om de kosten van overspecificatie te beperken, kan er ook voor worden gekozen om de specificaties van sommige eindproducten te beperken of de prestaties (zoals de bedrijfszekerheid) af te zwakken. In dat geval veroorzaakt gemeenschappelijkheid van onderdelen dus ook kosten als gevolg van teleurgestelde klanten, maar die kosten zijn veelal lastiger te kwantificeren.

- $\mathrm{Bij}$ de vorige punten gingen we ervan uit dat klanten niet op de hoogte waren van het feit dat (of het kan ze niets schelen dat) verschillende eindproducten voor een deel uit dezelfde onderdelen zijn opgebouwd. Maar er kunnen ook kosten verbonden zijn aan gemeenschappelijkheid van onderdelen doordat het imago van producten minder positief wordt en klanten niet meer bereid zijn een hogere prijs te betalen. Zo worden verschillende onderdelen gebruikt voor diverse types en merken van auto's binnen hetzelfde concern (zoals Volkswagen en General Motors), en dit kan leiden tot een mindere waardering van de duurdere merken (zoals Audi of Saab).

Een tweede thema in productontwikkeling dat relevant is voor de supply chain is het beperken en uitstellen van productdifferentiatie. Eigenlijk wordt het thema 'gemeenschappelijkheid' dan ruimer gezien dan alleen met betrekking tot onderdelen. Als ook subassemblages en hele modules gemeenschappelijk zijn, dan is het mogelijk om goederenstromen voor verschillende eindproducten langer bij elkaar te houden. Er is dan sprake van beperken en uitstellen van productdifferentiatie. Anders gezegd: er wordt naar gestreefd dat het aantal 'stock keeping units' (SKU's) zo min mogelijk toeneemt. Een SKU is een iets algemenere term dan bijvoorbeeld 'producttype' en verwijst naar entiteiten waarvan de voorraden afzonderlijk moeten worden bijgehouden (Lee en Tang, 1997). Stel bijvoorbeeld dat zes identieke blikjes bier op twee verschillende manieren worden verpakt: in een standaard kartonnen doosje en in een actieverpakking. Het zal duidelijk zijn dat deze items uit elkaar gehouden moeten worden, bijvoorbeeld in de voorraden, het transport en bij de facturering. Er is daarom sprake van twee verschillende SKU's. (De term 'product' is hier verwarrend: hoezo verschillende producten, het is toch bier, het is een hetzelfde blikje?) Er ontstaan in de supply chain al snel verschillende SKU's, bijvoorbeeld doordat producten met verschillende specificaties worden gemaakt, hetzelfde product op verschillende manieren wordt verpakt of exact hetzelfde product op verschillende locaties op voorraad wordt gelegd (Lee en Tang, 1998; Van Hoek, 2001).

Minder SKU's en meer gemeenschappelijkheid kan worden bereikt door aanpassingen van producten en van processen. Een fabrikant van disk drives voor pc's had een verschillend producttype voor iedere klant (zoals HP, IBM en Dell) als gevolg van verschillende instellingen op de disk drive, software en testprogramma's (Davila en Wouters, 2004, 2007). Het aanbrengen van deze verschillen veroorzaakte extra kosten. Bovendien werd de service voor klanten minder, omdat onverwachte, extra vraag van de ene klant niet kon worden opgevangen door gebruik te maken van de voorraad van een andere klant die op dat moment minder nodig had. Men is overgegaan op een standaard disk drive die geschikt was voor meerdere klanten. Dit werd mogelijk door aanpassingen aan verpakkingen, testprogramma's, software en hardware, en dit leidde tot lagere kosten en betere service. Een ander voorbeeld is dat HP printers heeft aangepast waardoor deze zowel in Europa als Noord-Amerika kunnen worden verkocht, terwijl deze eerder verschillend waren in verband met de stroomvoorziening (Feitzinger en Lee, 1997). Een voorbeeld van procesaanpassing is dat pc's pas in het distributiecentrum in Europa landspecifiek worden gemaakt (door middel van toetsenbord, handleiding, software-instellingen) in plaats van al in de fabriek in Singapore (Lee en Billington, 1995). Andere voorbeelden worden besproken door Skipworth en Harrison (2004) en Brown e.a. (2000).

Er zijn kostenvoordelen verbonden aan minder SKU's en meer gemeenschappelijkheid, zoals lagere voorraden en schaalvoordelen. Maar er zijn ook kosten, zoals van mogelijke overspecificatie.

Een derde thema in productontwikkeling dat relevant is voor de supply chain betreft modulair productontwerp. Een 
modulair ontwerp betekent dat een product bestaat uit verschillende fysieke delen, die elk een aantal volledige functies vervullen, die naast elkaar kunnen worden ontwikkeld, geproduceerd en getest, en die op verschillende manieren kunnen worden gecombineerd. Zie Mikkola $(2003,2006)$ en De Weerd-Nederhof e.a. (2007). Belangrijke onderdelen van bijvoorbeeld een vrachtwagen zijn het frame, de motor, de versnellingsbak, de assen, de brandstoftank en de cabine. Van elk onderdeel bestaan diverse varianten en deze kunnen op allerlei manieren worden gecombineerd om een enorm aantal verschillende eindproducten samen te stellen. Het ontwerp is modulair. Ten eerste, de onderdelen kunnen vooraf worden gemaakt en getest. Ten tweede, de interfaces zijn gestandaardiseerd, waardoor het aantal combinatiemogelijkheden toeneemt. Bijvoorbeeld, de aansluiting tussen de brandstoftank en grotere systeem is altijd hetzelfde. En bovendien zijn er standaardmodules die weinig invloed hebben op elkaar qua ontwerp: bijvoorbeeld de cabine hoeft niet speciaal te worden aangepast als deze met een bepaald type motor wordt gecombineerd.

Een modulair ontwerp biedt diverse voordelen.

- Het is een efficiënte manier om een groot aantal verschillende typen eindproducten te kunnen aanbieden. Een relatief beperkt aantal modules kan toch leiden tot een groot assortiment van eindproducten. Dit kan nog verder worden vergroot door in modules functionele opties in te bouwen die kunnen worden aan- of uitgezet.

- Er zijn schaalvoordelen bij de ontwikkeling, de inkoop en de productie van een geringer aantal verschillende modules, elk met een groter volume.

- Het is mogelijk om te werken met een gunstig klantorderontkoppelpunt. Door modules op voorraad te produceren, kan een korte levertijd worden gerealiseerd (in vergelijking met volledig op order produceren) en kunnen de voorraden worden beperkt (in vergelijking met volledig op voorraad produceren).

- Leveranciers kunnen worden betrokken bij de ontwikkeling van modules. Omdat modules zelfstandig een aantal functies vervullen, is het mogelijk om al vroeg met leveranciers te praten, namelijk als het ontwerp nog open is en alleen de functionele specificaties min of meer duidelijk zijn. In plaats van dat de leverancier wordt geconfronteerd met een volledig ontwerp, kan de expertise van deze leverancier worden benut om een slimmer ontwerp te maken. Dit is dus vooral van belang bij modules waarbij de leverancier wezenlijk kennis heeft van de module, wellicht zelfs meer kennis dan de opdrachtgever, bijvoorbeeld omdat het een technologie betreft die voor de opdrachtgever niet centraal staat maar die wel de 'core business' is van de leverancier (Henke en Zhang, 2010).

- Verder maakt een modulair ontwerp het mogelijk om volledige modules in te kopen. De leverancier kan zorgen voor de logistieke aansturing van de leveranciers verder stroomopwaarts (de zogenaamde 'second tier suppliers').

Aan de andere kant kan een modulair ontwerp ook leiden tot hogere kosten. De wens om modules in verschillende eindproducten in te kunnen bouwen, kan leiden tot kosten door overspecificatie, en de noodzaak om interfaces te standaardiseren brengt eventueel extra kosten met zich mee. De afweging is vergelijkbaar met gemeenschappelijkheid van onderdelen.

De gevolgen voor de controller en accountant kunnen zijn dat zij beslissingen over het productontwerp helpen financieel door te rekenen. Er zijn immers belangrijke voor- en nadelen verbonden aan keuzes zoals gemeenschappelijkheid van onderdelen en een modulair ontwerp. Naast technische en operationele overwegingen is een financiële berekening van belang om deze effecten tegen elkaar af te wegen. Dergelijke berekeningen worden vaak al gemaakt. Als de controller en accountant daarbij een rol willen spelen, dan moeten ze kennis hebben voorbij het strikt financiële om voldoende als partner te kunnen mee- en tegendenken.

\section{Risicobeheersing en andere gevolgen voor de controller en accountant}

We hebben een aantal ontwikkelingen in SCM besproken, met name economische afwegingen rond leverbetrouwbaarheid, stroomlijnen van Europese interne supply chains, de coördinatie van operationele activiteiten tussen bedrijven, productontwerp voor de supply chain. Door deze ontwikkelingen wordt risicobeheersing belangrijker. Immers, terugkerende thema's zijn afbouwen van onnodige buffers (zoals voorraden, reservetijd, overcapaciteit), consolidatie van de supply chain, verfijndere afstemming van processen (alleen mogelijk met geavanceerde informatiesystemen). Ook neemt de afhankelijkheid van leveranciers toe. Vandaar de aandacht voor risicomanagement (Chopra en Sodhi, 2004).

Risicocategorieën zijn onder meer: onderbreking van de aanvoer (bijvoorbeeld door brand of faillissement van een leverancier), vertraging in de aanvoer (bijvoorbeeld door file), falen van informatiesystemen, planning op basis van een verkeerde vraagvoorspelling, misbruik van intellectueel eigendom en sterk oplopende inkoopprijzen (bijvoorbeeld door wisselkoersen of afhankelijkheid van één leverancier).

Het treffen van maatregelen kost geld en daarom is het van belang een afweging te kunnen maken, zowel met betrekking tot hoeveel risico wordt afgedekt als met welke middelen. Maatregelen zijn voor een deel eerder genoemd bij het onderwerp 'market mediation', namelijk: voorraden, reservecapaciteit of een lagere service aan klanten accepteren. Denk hierbij niet alleen aan reservecapaciteit van machines, 
maar bijvoorbeeld ook aan het opleiden van oproepkrachten en deze zodanig aantrekkelijk betalen dat er daadwerkelijk voldoende mensen beschikbaar zijn als het nodig is. De 'verzekeringspremie' bestaat uit de extra kosten voor opleiden en hoger salaris in vergelijking met die van standaard uitzendkrachten. Daarnaast is het mogelijk te werken met meerdere leveranciers, zodat er gemakkelijker uitwijkmogelijkheden zijn bij onderbreking van de aanvoer en bij lastige prijsonderhandelingen als gevolg van afhankelijkheid. De 'verzekeringspremie' bestaat uit eventuele extra kosten, omdat er minder schaalvoordelen zijn (het volume wordt over meerdere leveranciers verdeeld) en omdat er vaste kosten zijn per leverancier (onafhankelijk van volume, zoals de kosten van een leveranciersaudit). Dit zijn de 'supplier sustaining costs' in termen van activity-based costing. Een andere maatregel is om ervoor te zorgen dat in het distributienetwerk snellere transportmodaliteiten kunnen worden gebruikt. Bijvoorbeeld, normaal gesproken wordt transport per boot gebruikt, maar er zijn ook contracten afgesloten om soms per vliegtuig spoedtransport te laten plaatsvinden.

Het is van belang om realistische risico's in de supply chain in kaart te brengen, mogelijke maatregelen op een rij te zetten en te kijken door welke combinatie van maatregelen op een efficiënte manier risico's kunnen worden verminderd.

Ook vatten we hier nog even samen welke andere gevolgen er kunnen zijn voor de controller en accountant (zie ook tabel 1).

- Beslissingen met betrekking tot market mediation moeten economisch kunnen worden onderbouwd (de afweging tussen de kosten van voorraad, flexibiliteit en nee-verkopen). Inzicht in deze kosten is echter vaak gefragmenteerd en de gevolgen van nee-verkopen zijn sowieso niet in de boekhouding te vinden.

- Stroomlijnen van de Europese supply chain kan leiden tot de noodzaak om prestatiemeting en kostprijsberekening meer te standaardiseren. Ook zullen deze systemen vaak moeten worden uitgebreid om een beter overzicht te krijgen van kosten en operationele prestaties op Europese schaal.

- Betere coördinatie van operationele activiteiten tussen bedrijven betekent dat men meer informatie met elkaar deelt en processen anders inricht. Dit heeft gevolgen voor informatiesystemen, maar ook voor de administratieve afhandeling van transacties en de manier waarop prestaties worden gemeten. Ook kostensystemen moeten worden aangepast om besparingsmogelijkheden te identificeren en effecten te kunnen volgen.

- Beslissingen over productontwerp hebben vergaande economische gevolgen in de supply chain. Ook hier mag worden verwacht dat deze door de controller kunnen worden onderbouwd. Denk bijvoorbeeld aan de afweging van de kosten en opbrengsten van een modulair ontwerp.

Prof. dr. ir. Marc Wouters is hoogleraar Management

Accounting aan de Universiteit Twente. Hij richt zich in

onderwijs en onderzoek op het gebruik van

bedrijfseconomische informatie buiten de financiële functie

zoals in logistiek, inkoop, manufacturing en

business-to-business marketing

\section{Literatuur}

- Brown, A., H. Lee en R. Petrakian (2000), Achieving supply chain excellence through product and process postponement in the semiconductor industry: The Xilinx case, Interfaces, vol. 30, pp. 65-80.

- Chopra, S. en M. S. Sodhi (2004), Managing risk to avoid supply-chain breakdown, MIT Sloan Management Review, vol. 46 (Fall), pp. 53-61.

- Cooper, R. en R. Slagmulder (2004),

Achieving full-cycle cost management, MIT Sloan Management Review, vol. 46 (Fall), pp. 45-52.

- Corbey, M. en R. Jansen (1993), The economic lot size and relevant costs, International Journal of Production Economics, vol. 30-31, pp. 519-530.
Davila, T. en M. Wouters (2004), Designing cost-competitive technology products: improving product development through cost management, Accounting Horizons, vol. 18, no. 1, pp. 13-26.

Davila, T. en M. Wouters (2007), An empirical test of inventory, service and cost benefits from a postponement strategy, International Journal of Production Research, vol. 45, no. 10, pp. 2245-2267.

- Feitzinger, E. en H. Lee (1997), Masscustomization at Hewlett-Packard; The power of postponement, Harvard Business Review, vol.75, no. 1 (January-February), pp. 116-121.

- Fisher, M.L. (1997), What is the right supply chain for your products? Harvard Business Review, vol. 75, no. 2 (March-April), pp. 105-116.
- Fransoo, J. en M. Wouters (2000), Measuring the bullwhip effect in a supply chain, Supply Chain Management, vol. 5, no. 2, pp. 78-89.

Golicic, S.L., C. N. Boerstler en L. Ellram (2010), 'Greening' transportation in the supply chain, MIT Sloan Management Review, vol. 51 no. 2 (Winter), pp. 25-31.

Groot, T. en M. Wouters (1999), Beheersing van multinationals: combineren van centrale sturing met locale autonomie, Tijdschrift voor Bedrijfsadministratie, vol. 103 (November), pp. 394-402.

- Henke Jr., J.W. en C. Zhang (2010), Increasing supplier-driven innovation, MIT Sloan Management Review, vol. 51, no. 2, (Winter), pp. 41-46. 
- Hoek, R.I. van, B. Vos en H.R. Commandeur (1999), Restructuring European supply chains by implementing postponement strategies, Long Range Planning, vol. 32, no. 5, pp. 505-518.

- Hoek, R. I. van (2001), The rediscovery of postponement: a literature review and directions for research, Journal of Operations

Management, vol. 19, pp. 161-184.

- Johnson, P.F. en M.R. Leenders (2010), Minding the supply savings gaps, MIT Sloan Management Review, vol. 51, no. 2 (Winter), pp. 25-31.

- Knaapen, A., E. van der Meer en M. Wouters (2003), Kostenanalyse ter ondersteuning van supply chain management in een Europese context, Accounting, vol. 107, no. 3, pp. 3-11.

- Kopczak, L.R. en M.E. Johnson (2003), The supply-chain management effect, MIT Sloan Management Review, vol. 44 (Spring), pp. 27-34.

- Labro, E. (2004), The cost effects of component commonality: a literature review through a management-accounting lens, Manufacturing and Service Operations Management, vol. 6, no. 4, pp. 358-367. - Lee, H.L. en C. Billington (1995), The evolution of supply-chain-management models and practice at Hewlett-Packard, Interfaces, vol. 25, pp. 42-63.

- Lee, H.L. en C.S. Tang (1997), Modelling the costs and benefits of delayed product differentiation, Management Science, vol. 43, pp. 40-53.

- Lee, H.L. en C. S. Tang (1998), Variability reduction through operations reversal, Management Science, vol. 44, pp. 162-172. - Lohman, C. L. Fortuin en M. Wouters (2004), Designing a performance measurement system - a case study, European Journal of Operational Research, vol. 156, no. 2, pp. 267-286.
- Melnyk, S.A., E.W. Davis, R.E. Spekman en J. Sandor (2010), Outcome-driven supply chains, MIT Sloan Management Review, vol. 51, no. 2 (Winter), pp. 33-38.

Mikkola, J.H. (2003), Modularity, component outsourcing, and inter-firm learning, $R \& D$ Management, vol. 33, no. 4, pp. 439-454.

- Mikkola, J.H. (2006), Capturing the degree of modularity embedded in product architectures, Journal of Product Innovation Management, vol. 23, no. 2, pp. 128-146.

- Miller, P. en T. O'Leary (2007), Mediating instruments and making markets: Capital budgeting, science and the economy, Accounting, Organizations and Society, vol. 32 , pp. 701-734.

- Morssinkhof, S., M. Wouters en L. Warlop (2005), Total cost of ownership en samenwerking tussen organisaties, Maandblad voor Accountancy en Bedriffseconomie, vol. 79 , no. 9, pp. 420-428.

-Ramdas, K. (2003), Managing product variety: an integrative review and research directions, Production and Operations Management, vol. 12, pp. 79-101.

- Randall, T. en K. Ulrich (2001), Product variety, supply chain structure, and firm performance: analysis of the U.S. bicycle industry, Management Science, vol. 47, pp. 1588-1604.

- Stewart, T.A. en L. O'Brian (2005), Execution without excuses, Harvard Business Review. vol. 83, no. 3 (March), pp. 102-111.

- Skipworth, H. en A. Harrison (2004), Implications of form postponement to manufacturing: a case study, International Journal of Production Research, vol. 42 , pp. 2063-2081.

- Tajima, M. (2007), Strategic value of RFID in supply chain management, Journal of
Purchasing and Supply Management, vol. 13, pp. 261-273.

שUlich, K. (1995), The role of product architecture in the manufacturing firm, Research Policy, vol. 24, pp. 419-440.

-Weerd-Nederhof, P.C. de, M. Wouters, S.J.A. Teuns en P.H. Hissel (2007), The architecture improvement method: cost management and systemic learning about strategic product architectures, R\&D Management, vol. 37, no. 5, pp. 425-439.

Wouters, M. (2006), Total cost of ownership voor inkoopbeslissingen, Tijdschrift voor Inkoop en Logistiek, no. 7/8 (July-August), pp. 10-14.

- Wouters, M. (2007), Implementation costs and redistribution mechanisms in the economic evaluation of supply chain management initiatives, Supply Chain Management: an International Journal, vol. 11, no. 6, pp. 510-521.

- Wouters, M., F. Wynstra en J.C. Anderson (2005), The adoption of total cost of ownership for sourcing decisions - a structural equations analysis, Accounting, Organizations and Society, vol. 30, no. 2, pp. 167-191.

-Wouters, M. en M. Sportel (2005), The role of existing measures in developing and implementing performance measurement systems, International Journal of Operations and Production Management, vol. 25, no. 11 pp. 1062-1082.

Wouters, M., T. Stertefeld, C. Wilderom (2007), Medewerkers maken KPIs op maat, In Logistiek, (September), pp. 12-19.

- Wouters, M. en C. Wilderom (2008), Developing performance measurement systems as enabling formalization: A longitudinal field study of a logistics department, Accounting, Organizations and Society, vol. 33, no. 4/5, pp. 488-515. 